\title{
Modelling efficient innovative work: integration of economic and social psychological approaches
}

\author{
Yulia Babanova ${ }^{1, *}$, Vera Gryazeva-Dobshinskaya ${ }^{2}$, and Yulia Dmitrieva ${ }^{2}$ \\ ${ }^{1}$ South Ural State University (national research university), Management of innovation in business Department, Chelyabinsk, \\ Russia
}

\begin{abstract}
The article deals with the relevance of integration of economic and social psychological approaches to the solution of enhancing the efficiency of innovation management. The content, features and specifics of the modelling methods within each of approaches are unfolded and options of integration are considered. The economic approach lies in the generation of the integrated matrix concept of management of innovative development of an enterprise in line with the stages of innovative work and the use of the integrated vector method for the evaluation of the innovative enterprise development level. The social psychological approach lies in the development of a system of psychodiagnostic indexes of activity resources within the scope of psychological innovative audit of enterprise management and development of modelling methods for the balance of activity trends. Modelling the activity resources is based on the system of equations accounting for the interaction type of psychodiagnostic indexes. Integration of two approaches includes a methodological level, a level of empirical studies and modelling methods. There are suggested options of integrating the economic and psychological approaches to analyze available material and non-material resources of the enterprises' innovative work and to forecast an optimal option of development based on the implemented modelling methods.
\end{abstract}

\section{Introduction}

In the context of stiffer competition and expedited changes in the social and economic areas, today's managers feel the need "to be the leaders of innovations" that are capable of performing complex tasks of managing innovative work in a project team. Formation of leadership competences requisite for the implementation of innovative projects is a relevant managerial task. Innovation management has certain specifics related to the actual innovative work, namely novelty and speed of changes, maintenance of the traditional long-term functioning, and risks, uncertainty and strain for all its subjects. Efficient management of the subjects' innovative work is determined by a complex of external (objective - technological, institutional and cultural) and internal (subjective social psychological and psychological) factors.

The study objective is the modelling of efficient innovative work based on the system integration of economic and social psychological technologies used at a number of its subjects' (individuals and organizations) activity levels. Within the scope of the economic approach, the study objects are enterprises that perform innovative work. The object of the social psychological approach is a manager that manifests one innovative activity or another.

Integration of two approaches (economic and social psychological) to the solution of the challenge of enhancing the efficiency of innovation management makes it possible to study available material and nonmaterial resources of the enterprises' innovative work in an integrated manner and to forecast the optimal option of their development.

\section{Economic approach}

The economic approach is based on the study of interconnection between the enterprises' management efficiency and their innovative activity. Modern enterprises are capable to various degrees to manage their own innovative activity. To enhance the efficiency of the innovative work management, the management concept must be improved in the part of integration of methodological economic and social psychological approaches $[1,2]$.

The generated integration matrix concept of managing innovative development of an enterprise comprises three fields that are hierarchically dependent structures reflecting the main factors of the enterprise's work $[1,3]$. The resource field, as an aggregate of indexes of the enterprise's material assets, represents production factors (labor, land, capital, information and others) requisite to maintain the enterprise functioning.

\footnotetext{
Corresponding author: dmitrieva.julia.86@mail.ru
} 
Table 1. Evaluation of the innovative state of an enterprise.

\begin{tabular}{|c|c|c|c|}
\hline $\begin{array}{l}\text { Horizontal } \\
\text { level }\end{array}$ & \multirow{2}{*}{$\begin{array}{l}\text { Novation } \\
\text { formation } \\
\text { stage } \\
\text { INPUT }\end{array}$} & \multirow{2}{*}{$\begin{array}{l}\text { Novation } \\
\text { transformation } \\
\text { into an } \\
\text { innovation } \\
\text { stage } \\
\text { MECHANISM }\end{array}$} & \multirow{2}{*}{$\begin{array}{l}\text { Innovation } \\
\text { commercializat } \\
\text { ion stage } \\
\text { OUTPUT }\end{array}$} \\
\hline $\begin{array}{l}\text { Vertical } \\
\text { level }\end{array}$ & & & \\
\hline $\begin{array}{l}\text { Mental } \\
\text { field of the } \\
\text { enterprise } \\
\text { MENTAL } \\
\text { FIELD }\end{array}$ & $\begin{array}{l}\text { MIn } \\
\text { Composite } \\
\text { index of the } \\
\text { mental field } \\
\text { development } \\
\text { that } \\
\text { determines the } \\
\text { quality of } \\
\text { input into the } \\
\text { innovative } \\
\text { process }\end{array}$ & $\begin{array}{l}\text { MM } \\
\text { Composite } \\
\text { index of the } \\
\text { mental field } \\
\text { development } \\
\text { that determines } \\
\text { the quality of } \\
\text { mechanism of } \\
\text { innovative work }\end{array}$ & $\begin{array}{l}\text { MOut } \\
\text { Composite } \\
\text { index of the } \\
\text { mental field } \\
\text { development } \\
\text { that determines } \\
\text { the quality and } \\
\text { number of } \\
\text { innovative } \\
\text { outputs }\end{array}$ \\
\hline $\begin{array}{l}\text { Knowledge } \\
\text { field of the } \\
\text { enterprise } \\
\text { KNOWLE } \\
\text { DGE } \\
\text { FIELD }\end{array}$ & $\begin{array}{l}\text { KIn } \\
\text { Composite } \\
\text { index of the } \\
\text { knowledge } \\
\text { field } \\
\text { development } \\
\text { that } \\
\text { determines the } \\
\text { quality of } \\
\text { input into the } \\
\text { innovative } \\
\text { process }\end{array}$ & $\begin{array}{l}\text { KM } \\
\text { Composite } \\
\text { index of the } \\
\text { knowledge field } \\
\text { development } \\
\text { that determines } \\
\text { the quality of } \\
\text { mechanism of } \\
\text { innovative work }\end{array}$ & $\begin{array}{l}\text { KOut } \\
\text { Composite } \\
\text { index of the } \\
\text { knowledge field } \\
\text { development } \\
\text { that determines } \\
\text { the quality and } \\
\text { number of } \\
\text { innovative } \\
\text { outputs }\end{array}$ \\
\hline $\begin{array}{l}\text { Resource } \\
\text { field of the } \\
\text { enterprise } \\
\text { RESOURC } \\
\text { E FIELD }\end{array}$ & $\begin{array}{l}\text { RIn } \\
\text { Composite } \\
\text { index of the } \\
\text { resource field } \\
\text { development } \\
\text { that } \\
\text { determines the } \\
\text { quality of } \\
\text { input into the } \\
\text { innovative } \\
\text { process }\end{array}$ & $\begin{array}{l}\text { RM } \\
\text { Composite } \\
\text { index of the } \\
\text { resource field } \\
\text { development } \\
\text { that determines } \\
\text { the quality of } \\
\text { mechanism of } \\
\text { innovative work }\end{array}$ & $\begin{array}{l}\text { ROut } \\
\text { Composite } \\
\text { index of the } \\
\text { resource field } \\
\text { development } \\
\text { that determines } \\
\text { the quality and } \\
\text { number of } \\
\text { innovative } \\
\text { outputs }\end{array}$ \\
\hline
\end{tabular}

The knowledge field, as an aggregate of indexes of non-material assets, represents the system of accumulated knowledge, skills, capacities and competences that are implemented to turn the resource field factors into the final product of the enterprise's work. The mental field, as an aggregate of indexes of the enterprise's intangible assets, represents the system of values, strategic benchmarks and overall corporate culture (table 1).

The stages of innovative work, namely formation of ideas, implementation of an introduced novation and commercialization of an innovation, superimpose on the field structure of the enterprise $[4,5,6]$. The aggregate of indexes at the cross-section of all elements enables to determine the level of the enterprise's innovative development (fig. 1).

The method allows detecting an innovative state of the enterprise and forecasting its future development.

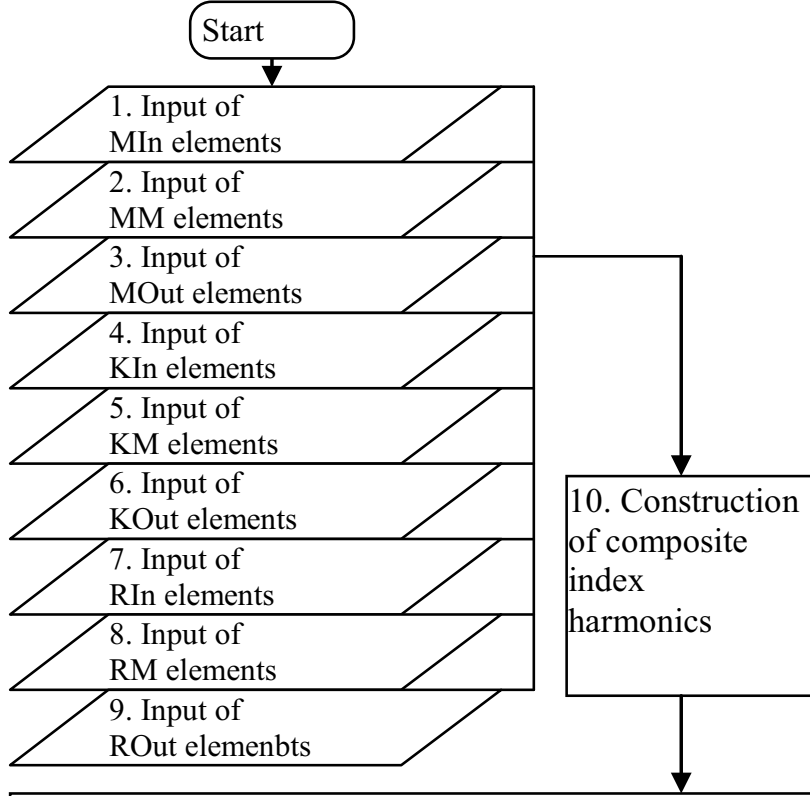

11. Evaluation of correlation relationships of composite indexes

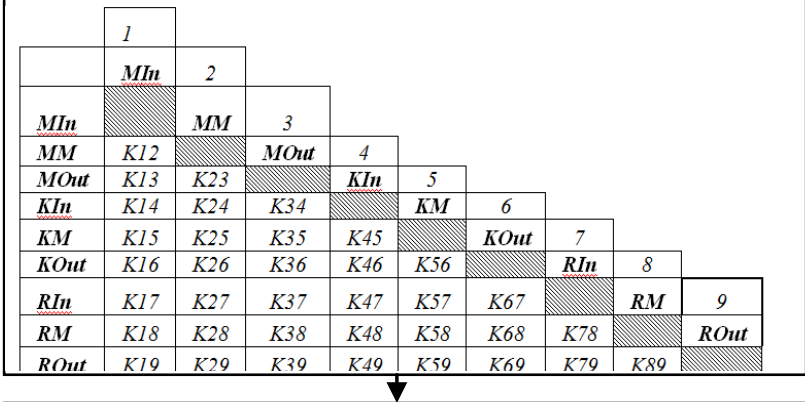

12. Determination of the range of indexes with correlation relationships.

For instance:

Af1 $=$

$\mathrm{A} 1+\mathrm{K} 12 \times \mathrm{A} 2+\mathrm{K} 13 \times \mathrm{A} 3+\mathrm{K} 14 \times \mathrm{A} 4+\mathrm{K} 15 \times \mathrm{A} 5+\mathrm{K} 16 \times \mathrm{A} 6+$

$+\mathrm{K} 17 \times \mathrm{A} 7+\mathrm{K} 18 \times \mathrm{A} 8+\mathrm{K} 19 \times \mathrm{A} 9$

13. Range standardization. For instance:

$\mathrm{A}_{\mathrm{f}^{*}}=\mathrm{A}_{\mathrm{f}} / \sum\left(\mathrm{A}_{\mathrm{f}}+\mathrm{B}_{\mathrm{f}}+\mathrm{C}_{\mathrm{f}}+\ldots+\mathrm{J}_{\mathrm{f}}\right)$

14. Calculation of instant values of standardized interdependent indexes: $\mathrm{a}_{\mathrm{f}}=\mathrm{A}_{\mathrm{f}^{*}} \times \cos \Delta \mathrm{a}$

15. Construction of integral harmonic:

$\mathrm{Y}_{\mathrm{f}}=\mathrm{a}_{\mathrm{f}}+\mathrm{b}_{\mathrm{f}}+\mathrm{c}_{\mathrm{f}}+\mathrm{d}_{\mathrm{f}}+\mathrm{e}_{\mathrm{f}}+\mathrm{f}_{\mathrm{f}}+\mathrm{g}_{\mathrm{f}}+\mathrm{h}_{\mathrm{f}}+\mathrm{j}_{\mathrm{f}}$

\begin{tabular}{|l|l|l|l|l|l|l|}
\hline 16. Interpretation of the innovative state level based on Harrington scale \\
\hline Absence & Low & Below & Average & Above & High & Very \\
aver 0.09] $]$ & {$[0.10 ;$} & average & {$[0.50 ;$} & {$[0.90 ;$} & high \\
& $0.27]$ & $0.28 ;$ & $0.79]$ & $0.71 ;$ & $0.99]$ & {$[1.00]$} \\
& & $0.49]$ & & $0.89]$ & & \\
\hline
\end{tabular}

Fig. 1. Integration vector method of evaluation of the innovative state. 


\section{Social psychological approach}

The social psychological approach to the management of innovative work draws on the understanding of general requirements to the psychological resources of managers to unfold all stages of an idea transforming into an innovation. This approach is aimed to detect an individual profile and resource level of managers according to a generated index system. This index system is implemented in mathematical models: to forecast the development activity of managers, to determine an optimal option of an individual leader and his/her team using psychological resources and to form new managerial competences in an efficient manner.

Modern psychological technologies of managing the innovative work are aimed at the controlled stimulation of various stages of the innovative process, starting the author's creative idea to its commercialization by the project team, and at the work efficiency enhancement [715]. Within the scope of these technologies, there are used various index systems, including indexes of the leadership styles and management styles, motivation structure, creativity structure, and structure of the organizational cultural attitudes [16-20].

The core of the generated concept of the psychological innovative audit aimed to study the prospects of leadership implementation in the innovation is the notion of innovative leadership [21]. Innovative leadership is perceived as a complex system phenomenon that has two subsystems - focusing the activity on the change and focusing the activity on the retention of the functioning parameters, and various levels of the activity manifestation: intra-, inter- and meta-individual levels (table 2). The intra-individual activity level includes motivational, intellectual-andcreative and existential-and-personal resources. The inter-individual activity level includes team-oriented, management and leadership resources. The metaindividual activity level reflects the sociocultural identity and the organizational culture attitudes [22].

To determine all of the aforementioned indexes, there is a diagnostic toolset available that has been standardized and validated on the selections of enterprise managers with different innovative development levels [2].

See the indexes of the managers' activity resources to determine the resources of innovative leadership in line with the three specified levels in table 2 below.

Based on the factor analytical study of the outcomes of psychological diagnostics of the managers' innovative leadership resources, a two-factor structure for the activity resources (creative, motivational, leadership) was discovered. Detection of this structure confirms an existence of two (search and stabilizing) activities in the managers [23]. By now, based on the factor analytical study of the outcomes of psychological diagnostics of the managers' innovative leadership resources (leadership, creative, motivational and team-and-role), two levels of innovative leadership have been detected: intra- and inter-individual ones [24].

In the practice of the psychological innovative audit, there was revealed a problem of the general evaluation of the managers' activity resources where a great number of psychodiagnostic indexes is present (table 2). For this purpose, there was developed a calculation technology for the integral indexes of activity based on the modelling methods.

Table 2. Indexes of the managers' activity resources.

\begin{tabular}{|c|c|c|}
\hline $\begin{array}{l}\text { Activity } \\
\text { levels }\end{array}$ & $\begin{array}{l}\text { Resources of the } \\
\text { managers' } \\
\text { searching activity } \\
\text { focused on the } \\
\text { change }\end{array}$ & $\begin{array}{l}\text { Resources of the } \\
\text { managers' } \\
\text { stabilizing activity } \\
\text { focused on the } \\
\text { retention }\end{array}$ \\
\hline \multirow[t]{4}{*}{$\begin{array}{l}\text { Intra- } \\
\text { individual }\end{array}$} & $\begin{array}{l}\text { Motivation - } \\
\text { "hoping for } \\
\text { success" }\end{array}$ & $\begin{array}{l}\text { Motivation - "failure } \\
\text { avoidance" }\end{array}$ \\
\hline & $\begin{array}{l}\text { Personal choice } \\
\text { type (creative) }\end{array}$ & $\begin{array}{l}\text { Personal choice } \\
\text { type (realistic) }\end{array}$ \\
\hline & $\begin{array}{l}\text { Creative thinking } \\
\text { (flexibility, } \\
\text { original mindset) }\end{array}$ & Intellectual control \\
\hline & $\begin{array}{l}\text { Active non- } \\
\text { adaptiveness } \\
\text { (intellectual } \\
\text { initiative and } \\
\text { emotional } \\
\text { reactivity) }\end{array}$ & $\begin{array}{l}\text { Adaptiveness } \\
\text { (realistic perception; } \\
\text { anxiety) }\end{array}$ \\
\hline \multirow[t]{2}{*}{$\begin{array}{l}\text { Inter- } \\
\text { individual }\end{array}$} & $\begin{array}{l}\text { Transformational } \\
\text { leadership }\end{array}$ & $\begin{array}{l}\text { Transactional } \\
\text { leadership }\end{array}$ \\
\hline & $\begin{array}{l}\text { Team-and-role } \\
\text { identification } \\
\text { (by role: idea } \\
\text { generator, resource } \\
\text { prospector, } \\
\text { motivator, analyst) }\end{array}$ & $\begin{array}{l}\text { Team-and-role } \\
\text { identification } \\
\text { (by role: } \\
\text { implementer, } \\
\text { controller, } \\
\text { coordinator, } \\
\text { harmonizer) }\end{array}$ \\
\hline \multirow[t]{4}{*}{$\begin{array}{l}\text { Meta- } \\
\text { individual }\end{array}$} & $\begin{array}{l}\text { Tolerance towards } \\
\text { creative personnel } \\
\text { (to the roles of a } \\
\text { creator and a } \\
\text { crisis-time } \\
\text { rescuer) }\end{array}$ & $\begin{array}{l}\text { Intolerance towards } \\
\text { creative personnel } \\
\text { (to the roles of a } \\
\text { creator and a crisis- } \\
\text { time rescuer) }\end{array}$ \\
\hline & $\begin{array}{l}\text { Values of } \\
\text { cognition, freedom }\end{array}$ & $\begin{array}{l}\text { Values of labor, } \\
\text { supremacy }\end{array}$ \\
\hline & $\begin{array}{l}\text { Innovative and } \\
\text { humanistic } \\
\text { management } \\
\text { orientations }\end{array}$ & $\begin{array}{l}\text { Bureaucratic and } \\
\text { autocratic } \\
\text { management } \\
\text { orientation }\end{array}$ \\
\hline & $\begin{array}{l}\text { Organizational } \\
\text { culture attitudes: } \\
\text { team-oriented, } \\
\text { mobile }\end{array}$ & $\begin{array}{l}\text { Organizational } \\
\text { culture attitudes: } \\
\text { paternalistic, } \\
\text { pyramidal }\end{array}$ \\
\hline
\end{tabular}

The generated method to model the managers' activity resources is based on various types of indexes interaction within each of the subsystems (search and stabilizing activity): "cooperation", "competition", "predator vs victim" and "neutralism" $[25,26]$. It is determined that the optimal type of index interaction when modelling the structural activity resources is "cooperation" [27]. 
Table 3. Integral indexes of the managers' activity resources.

\begin{tabular}{|l|l|l|}
\hline $\begin{array}{l}\text { Activity } \\
\text { levels }\end{array}$ & $\begin{array}{l}\text { Resources of the } \\
\text { managers } \\
\text { searching activity } \\
\text { focused on the } \\
\text { change }\end{array}$ & $\begin{array}{l}\text { Resources of the } \\
\text { managers } \\
\text { stabilizing } \\
\text { activity focused } \\
\text { on the retention }\end{array}$ \\
\hline $\begin{array}{l}\text { Intra- } \\
\text { individual }\end{array}$ & $\begin{array}{l}\text { Ym } \\
\text { Integral index for } \\
\text { motivational } \\
\text { resources }\end{array}$ & $\begin{array}{l}\text { Xm } \\
\text { Integral index for } \\
\text { motivational } \\
\text { resources }\end{array}$ \\
\cline { 2 - 3 } & $\begin{array}{l}\text { Ycr } \\
\text { Integral index for } \\
\text { creative resources }\end{array}$ & $\begin{array}{l}\text { Xcr } \\
\text { Integral index for } \\
\text { creative resources }\end{array}$ \\
\hline Inter- & $\begin{array}{l}\text { Yl } \\
\text { Integral index for } \\
\text { leadership } \\
\text { resources }\end{array}$ & $\begin{array}{l}\text { Xl } \\
\text { Integral index for } \\
\text { leadership } \\
\text { resources }\end{array}$ \\
\cline { 2 - 3 } & $\begin{array}{l}\text { Yr } \\
\text { Integral index for } \\
\text { team-and-role } \\
\text { resources }\end{array}$ & $\begin{array}{l}\text { Xr } \\
\text { Integral index for } \\
\text { team-and-role } \\
\text { resources }\end{array}$ \\
\hline
\end{tabular}

Mathematical modelling of activity resources was performed individually for each manager based on the system of 2 linear equations. The first equation describes resources of the search activity that is focused on the change (y variable) and the second equation describes resources of the stabilizing activity focused on the retention ( $\mathrm{x}$ variable). Ratios $\mathrm{a} 1, \mathrm{a} 2, \mathrm{c} 1$ and $\mathrm{c} 2$ equal psychodiagnostic indexes of the relevant activity resources.

The overall look of this equation system is set forth below:

$$
\begin{aligned}
& \mathrm{a} 2+\mathrm{x}-\mathrm{c} 2 * \mathrm{y}=0 \\
& \mathrm{a} 1+\mathrm{y}-\mathrm{c} 1 * \mathrm{x}=0
\end{aligned}
$$

Solution of the above equation system enables us to calculate $\mathrm{Y}$ and $\mathrm{X}$ coordinates which represent, in the Cartesian system (on the plane quadrant), the values of competing parameters for each activity trend.

This method allows calculating integral indexes of the managers' activity that accounts not simply for the aggregate of all psychodiagnostic indexes but also for their structure and interaction types for each activity resource (table 3).

Based on the modelling method, the overall evaluation of the managers' activity resources is performed; the shift from a greater number of psychological diagnostics indexes to two integral indexes for each activity resource is ensured; the balance of activity trends for each resource is determined; and the range of the resource optimum for an efficient performance of innovative work is forecasted.

\section{Integration of economic and social psychological approaches}

Integration of economic and social psychological approaches to the innovative work modelling is performed both at the level of the general academic methodology (system approach to the study of innovative activity of subjects) and at the level of empiric studies (generation of the unified system of the innovative activity indexes) and modelling methods (generation of the overall evaluation model for the level of an enterprise's innovative development).

Integration of the economic and social psychological approaches to the modelling of efficient innovative work is possible in three options.

The first option lies in analyzing the coordination of outcomes of economic and social psychological technologies, including the numerical analysis of compliance of the evaluation results for an innovative development level at various enterprises. One of the methods of such study can be the discriminant analysis where the economic index of non-material resources, i.e. evaluation of the enterprise's innovative development level (knowledge field) acts as a single independent variable and the psychological indexes act as dependent variables that are parts of the structure matrix with various scores.

The second option lies in using the psychological diagnostics results as the managers' activity resource indexes (social psychological approach) in the system of basic data of the integration vector method for evaluation of the innovative state of an enterprise.

The third option lies in using integral indexes as results of the modelling psychological diagnostics data (social psychological approach) in the system of basic data of the integration vector method for evaluation of the innovative state of an enterprise.

\section{Conclusion}

Thus, the modelling of efficient innovative work based on the system integration of economic and social psychological technologies demonstrated that innovative development of an enterprise is determined by factors formed at the social psychological level of the manager's personality and his/her team, thereby proving the feasibility of integration of these approaches for a further study and implementation in the applied consulting.

Integration of the economic and social psychological approaches to the modelling of innovative activity resources enables to evaluate the activity resource level of both individual managers or management teams and overall enterprises more precisely.

The modelling of the subjects' innovative development level allows constructing more efficient programs of training the personnel in new competences essential for the expansion of the innovative work.

The work was supported by Act 211 Government of the Russian Federation, contract № 02.A03.21.0011.

\section{References}

1. Y.V. Babanova, N.V. Kireeva, SUSU newsletter, Economy and Management series, 3, 7 (2013)

2. V.G. Gryazeva-Dobshinskaya, Y.A. Dmitrieva, Resources of innovative leadership managers: 
psychological innovative audit (SUSU publishing house, Chelyabinsk, 2016)

3. Y.V. Babanova, V.P. Gorshenin, SUSU newsletter, Economy and Management series, 22 (2012)

4. A.E. Luzin, Y.V. Babanova, Management in Russia and abroad, 6 (2013)

5. Van M. Assen, Van den Berg, G.P. Pitersma, Key management model. 60 models that every manager needs to know (Bean. Knowledge Laboratory, Moscow, 2011)

6. P. Ericksen, R. Suri, El-Jawhari, APICS Magazine, 15 (2005)

7. T. Amabile, How to Kill Creativity Creative thinking in business (Alpina Business Books, Moscow, 2006)

8. R.L. Daft, The Leadership Experience (EKSMO, Moscow, 2007)

9. I.K. Adizes, Management/Mismanagement Styles (Alpina Publishers, Moscow, 2011)

10. G. Van Wulfen, The Innovation Expedition. A visual toolkit to start innovation (Mann, Ivanov and Ferber, Moscow, 2014)

11. H. Courtney, J. Kirkland, P. Viguerie, Strategy under Uncertainty, Management under Uncertainty (Alpina Business, Moscow, 2006)

12. P.F. Drucker, Innovation and Entrepreneurship (OOO I.D. Williams, Moscow, 2007).

13. A. Hargadon, Management of innovations (OOO I.D. Williams, Moscow, 2007)

14. D. Dile, G. Cangemi, C. Kowalski, Psychology, Higher School of Economics Journal, 2, 1 (2004)
15. I.K. Adizes, Leading the Leaders, How to Enrich Your Style of Management and Handle People Whose Style is Different from Yours (Alpina Business Books, Moscow, 2009)

16. G. Fischer, Psychology, Higher School of Economics Journal, 4, 2 (2005)

17. B.J. Avolio, B.M. Bass, D.I. Jung, Journal of Occupational and Organizational Psychology (1999)

18. Y.D. Krasovsky, Sociocultural fundamentals of managing a business organization (UNITY-DANA, Moscow, 2007)

19. A.A. Tikhomirov, U.D. Spangler, Russian management journal, 2, 3 (2005)

20. V.G. Gryazeva-Dobshinskaya, Social psychology of creative work - 2007: collection of treatises (2007)

21. V.G. Gryazeva-Dobshinskaya, SUSU newsletter, Psychology series, 9 (2010)

22. V.G. Gryazeva-Dobshinskaya, Y.A. Dmitrieva, SUSU newsletter, Psychology series, 1, 9 (2016)

23. Y.A. Dmitrieva, SUSU newsletter, Psychology series, 3, 8 (2015)

24. V. Volterra, Mathematical Theory of the Struggle for Existence (Institute of computer research, Moscow, 2004)

25. V.G. Gryazeva-Dobshinskaya, Y.A. Dmitrieva, South Ural State University newsletter, Psychology series, 13 (2011)

26. V.G. Gryazeva-Dobshinskaya, Y.A. Dmitrieva, Leadership in innovations: modelling the managers' activity resources: monography (SUSU publishing house, Chelyabinsk, 2016) 